\title{
THE IMPULSE TOWARD THE DISADVANTAGED IN THE GOSPEL PREACHED BY PAUL: AN ANALYSIS OF 1 CORINTHIANS 1:10-4:21 AND 8:1-11:1
}

\author{
Dustin W Ellington \\ Department of Biblical Studies \\ Justo Mwale University
}

Department of New Testament University of the Free State

\begin{abstract}
This article examines two major sections of 1 Corinthians, 1:10-4:21 and 8:1-11:1, arguing that we find within Paul's gospel of Christ crucified an impulse to elevate the position of the disadvantaged. In both sections the gospel serves as Paul's resource for working toward just and unified relations in the Corinthian congregation. The study of 1 Cor. 1:10-4:21 traces the apostle's own identification with the cross and with disadvantaged members of the church. Paul's call to imitate himself becomes a means of imparting to the whole congregation a new identity as a people of power, as they embrace the way of the cross and the apostles. The reading of 1 Cor. 8:1-11:1 exhibits Paul's use of Christ's death for the 'weak' as a model for his own personal adjustments on behalf of the gospel and in deference to the vulnerable. By imitating Paul, the Corinthians can work with, not against, the gospel's impulse to honour the disadvantaged.
\end{abstract}

Key Words: Cross; Disadvantaged; Gospel, Imitate; Power; Status

\section{Introduction ${ }^{1}$}

Christians have long recognised a strong concern for the vulnerable in certain parts of the New Testament, such as the teachings of Jesus (e.g., Luke 4:16-30) and the letter of James (e.g., James 2:1-6). Yet, what about the writings of the apostle Paul? This apostle's letters have been vital in originating what Christians believe. Since the Reformation almost five hundred years ago, Protestants have relied particularly on Paul for the gospel of salvation through faith in Jesus Christ, by means of his death on the cross. Yet Paul's letters, with their emphasis on the gospel of Christ's death and resurrection, are sometimes thought to

This article expands upon a significantly shorter essay presented to the Council of Churches in Zambia (September 5, 2014).With the title, "The Impulse toward the Disadvantaged in the Gospel Preached by Paul: Reflecting on 1 Corinthians for Zambia's Jubilee," the earlier version also appeared in Word and Context (2014), a publication of Justo Mwale University in Lusaka, Zambia, to honour the fiftieth anniversary of Zambia's independence on October 24, 2014. 
overlook social concerns, and even to disregard the poor. ${ }^{2}$ In this essay, I will argue that Paul had an impulse toward the disadvantaged and that he experienced this impulse arising from the same gospel he preached for people's salvation. Paul's convictions about the gospel of Jesus' death on the cross shaped his concern for justice and for the disadvantaged.

I will concentrate on 1 Corinthians, a letter which, along with 2 Corinthians, provides the most in-depth portrayal of Paul's interaction with a particular congregation. 1 Corinthians also affords the opportunity to study how the apostle handles congregational issues which have a perceptible socio-economic component. After a brief bird's-eye view of the situation in Corinth and its fledgling congregation of believers, we will examine two major sections, 1 Cor. 1:10-4:21 and 8:1-11:1. ${ }^{3}$ As two of the largest segments of 1 Corinthians, they offer substantial material for a clarifying analysis. ${ }^{4}$ However critically important Christ crucified is for the gospel Paul preached for believers' salvation, we will discover that in these broad sections of 1 Corinthians, Paul focuses on the gospel of Christ crucified in order to re-align relationships among believers. The gospel becomes Paul's resource for working toward relations which are just and unified, especially for the sake of the church's less advantaged members. ${ }^{5}$ Our analysis will trace the gospel's role in Paul's tendency toward elevating the disadvantaged.

\section{The Situation of the Corinthian Church and Paul's Strategic Response ${ }^{6}$}

In the time of Paul the apostle, ancient Corinth was a prosperous city, defined by competition for status and success (Thiselton 2006:325, 326). In contrast with other cities of Paul's day, it was distinctly a place of opportunity and upward mobility - where a migrant craftsman might become a comfortable business owner - and this fed the ambitions of many who journeyed to Corinth with hopes of taking part in the city's fortune. Corinth was a centre of opportunity partly because of its relatively recent history. Rome had completely destroyed Corinth just over two centuries before Paul's arrival, but in 44 BC Julius Caesar re-founded it in honour of himself, as a colony of Rome and capital of the province of Achaia. The absence of a previously-landed class made Corinth attractive to colonists. Romans living in the East, Greek freed slaves, and hordes of day labourers made

2 See "Paul's Alleged Disregard of the Poor" in Longenecker (2010:1-16).

3 This study, however, does not exhaust the relevant material in 1 Corinthians. 1 Cor. 6:1-11 would also be

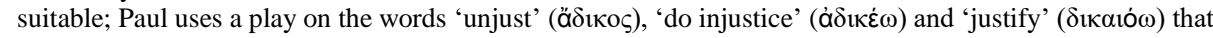
tends to be hidden in translation. The apostle repeats the same stem from all of these words to describe acts of injustice, only to make a statement at the end about the power of justification to create doers of justice (Gorman 2011:32-34). Paul's words regarding the Lord's Supper (1 Cor. 11:17-34) present another possibility for exploration. The apostle draws together the proclamation of Christ's death and regard for the poor; see the brief but perceptive comments of Downs (2009:151).

4 The letter conveniently divides in the following way: $1: 1-9 ; 1: 10-4: 21 ; 5: 1-6: 20 ; 7: 1-40 ; 8: 1-11: 1 ; 11: 2-34$; 12:1-14:40; 15:1-58; and 16:1-24. This outline roughly agrees with Hays (1997:xi-xiv), except that he considers 11:2-14:40 to be a unit.

$5 \quad$ Boff (1987:79) argues that the altercations among the Corinthian Christians lead Paul to develop his theology of Christ crucified. While this would be difficult to prove, Boff is correct to recognise that the death of Jesus becomes Paul's resource for dealing with and thinking theologically about the community's conflicts.

6 The information on Corinth is based on material in my introduction to 1 Corinthians in God's Justice: The Holy Bible (ed. T Stafford, 2016). For recent, in-depth exploration of the socio-religious context of ancient Corinth, see Friesen, Schowalter, and Walters (2010) and Schowalter and Friesen (2005). 
their way to Corinth. ${ }^{7}$ The city gained a reputation as a magnet for entrepreneurs, and great numbers of the poor flocked there, hoping to find a better life.

By the time Paul writes 1 Corinthians, the local culture's obsession with upward movement in status is getting the best of the young church (Hansen 2010:110). Members are boasting that one Christian leader is more eloquent and knowledgeable than another, and people have begun taking sides (1 Cor. 1:12). Envy and strife fill the congregation (1 Cor. $1: 11 ; 3: 3$ ). Believers have begun to take one another to court (1 Cor. 6:1-8). The Lord's Supper is apparently divided by social class, with some of the poorest even going without (1 Cor. 11:20-22). Believers rival one another by showing off their charismatic gifts (chapters 12 and 14).

Recognising that fixation upon status and power has taken over the congregation and is the root problem, Paul chooses to disrupt the Corinthian Christians' instincts about where to place their pride. He takes a strategy of turning upside down their sense of what is high and what is low in their pursuit of status and power. Paul especially finds the gospel of Christ crucified on behalf of others, with its patterns of power-in-weakness and sacrifice on behalf of others, to be the resource he needs for responding to the Corinthians (see also Malcolm 2013:161-163; Pickett 1997:37; Boff 1987:81, 83). Paul had preached the message of Christ crucified, and he affirms that the Corinthians received this gospel for their salvation (1 Cor. 15:1-2). They believed the gospel, but they had not yet learned how the gospel also orients the Christian way of life, including the redefinition of status and power in light of the cross. ${ }^{8}$ So in 1 Corinthians Paul aims to take the congregation to a deeper, better understanding of the gospel he first preached to them, in a way that speaks directly to the congregation's strife.

\section{Validation and Empowerment for the Disadvantaged: 1 Corinthians 1:10-4:21}

Once Paul names the congregation's divisions and quarrelling (1 Cor. 1:10-11), he turns their attention in the rest of 1 Corinthians 1-4 to the message and implications of the cross. The Corinthians are attracted to wisdom and power; Paul responds by redefining these through the gospel of Christ crucified (1:18). Paul utilises the cross as a metaphor for calling into question and reversing the social conventions of the Corinthian congregation. "We preach Christ crucified: to Jews a stumbling block, and to Gentiles foolishness, but to those who are called, both Jews and Gentiles, Christ the power of God and wisdom of God" (1:23-24). The apostle attempts to pull up the roots of Corinthian disunity by showing that God's power works in people and arenas that resemble the cross (1:18-31).

Paul recalls that hardly any of the Corinthian church members are, by their society's standards, wise, powerful, or well-born (1 Cor. 1:26). ${ }^{9}$ Their backgrounds resemble for Paul how most people in their world esteem the cross - foolish, weak, and of low regard (1:1718, 23-24). ${ }^{10}$ Moreover, as Paul affirms the arenas where God has chosen to exert power,

Millis (2010) demonstrates that the greatest number of colonists was a combination of Romans who had already been living in the East and Greek freedmen.

$8 \quad$ See Gorman 2001:298-301, 303; Malcolm 2013:34, 38, 148, 153; Boff 1987:78-82; Hurtado 2004; and Ellington 2011. See also Eastman (2010) on how Paul's gospel involves a union between kerygma and ethics.

9 Longenecker (2010:143) also sees the term 'weak' (1:27) as having an economic dimension in the context of 1 Cor. 1:26-29.

10 Meggitt (1997:66) calls crucifixion "the ultimate symbol of degradation for a slave". Nguyen (2008:36) states that spectacles of death, such as crucifixion, were normally for "condemned criminals of low status". Nguyen (2008:38-39) goes on to describe how the Roman arena, as a place for death spectacles, was a setting for establishing and upsetting social hierarchy. 
his Greek language shifts from references that are specific to the Corinthians in 1:26 to neuter references which are more general and inclusive (foolish, weak, base, and despised things) in 1:27-28 (Barrett 1968:58). The apostle thereby generalises that this is the way God tends to work, and not that it has merely happened this way in Corinth. God chose things that are low and despised "so that no one may boast" (1:30). Paul re-interprets the humble background of most of the Corinthians as something that sets them up as favoured. For the apostle, they are the sort of people who fit the pattern of how God reveals his power - in the midst of human weakness.

Paul also reminds the Corinthians of his own personal example. The apostle states that when he lived and preached among them, he came not with sophisticated rhetorical persuasion but in weakness, fear and trembling, so that their faith might not be in human wisdom but in God's power (1 Cor. 2:3-5; cf. 2 Cor. 11:6). ${ }^{11}$ Even though the Corinthians saw nothing in Paul worth boasting about, they apparently sensed strong evidence of God's power working through him as they came to faith.

This is the first occurrence in 1-2 Corinthians where the apostle speaks explicitly of his ministry in terms of power in weakness. It could hardly be more significant that we find these statements immediately following his description of the message of the cross, the gospel, in like terms ( 1 Cor. 1:18ff.). The fundamental pattern of God's power dwelling and being expressed in human weakness is one to which Paul will return again and again in his correspondence with the Corinthians (e.g., 1 Cor. 15:10; 2 Cor. 4:7; 12:9-10; 13:4). The pattern of power-in-weakness arises from the event and message of Christ crucified; Paul interprets his own life and ministry in the light of this gospel message. ${ }^{12}$ As he writes letters to the Corinthians, he wants their congregation to learn to do the same.

So Paul describes himself continuously as a weak vessel through whom God works powerfully. Gerd Theissen (1982:58) has observed of Paul's self-description in 1 Corinthians, "He places himself on the low end of the social hierarchy." Why does Paul do this, and what is the significance of his doing it in a portion of 1 Corinthians which culminates in the words, "Become imitators of me" (4:16)?

Paul's self-description as weak aligns him with the very thing through which God has chosen to reveal his power: the cross. Christ "was crucified in weakness", yet this same event unleashed the power of God for salvation (1 Cor. 1:17-18; 2 Cor. 13:4). God chose not the strong, but the weak things of the world, to display his power (1 Cor. 1:27). Paul's alignment of himself with the weakness of the cross authenticates his apostolic ministry as a suitable arena for God's power. When Paul embodies the gospel in his person, he comes across as weak by conventional Corinthian standards. Simultaneously, however, he strengthens his status and authority by the measure of the cross (Schutz 2007). If the Corinthians accept Paul's words that identify God's power in the cross, this will also strengthen Paul's authority and reputation vis-à-vis the Corinthian congregation. Paul's

11 See also Shi (2008:159). Moreover, Fitzmyer (2007:173) states: "Paul is rejecting explicitly the art of persuasion cultivated by the orators trained in Greco-Roman rhetorical tradition." Paul's style of writing, in which he engages in thoughtful persuasion, may have been different to his speaking. Malcolm (2013:137) may be on the mark when, following Winter (2002), he interprets Paul as saying he rejects the kind of oratory represented by the Sophists, in which truth is not the chief matter but rather human oratorical skill. Similarly, Ciampa and Rosner (2010:117) assert that "the sophist's goal was persuasion by the manipulation of arguments and skilful rhetoric. Paul's goal was the manifestation of God's power in people's lives."

12 Eastman's study of Philippians, which speaks of "the power of mimetic performance to evoke a corresponding mimesis by the audience" (2010:20), is also highly relevant for studying the function of Paul's example in 1 Corinthians. 
self-lowering mirrors the weakness of the cross, even as his proclamation of salvation reflects its power (1 Cor. 2:4-5).

The apostle's power in weakness also stands to solidify his connection with the Corinthian congregation, even as it validates the background of most of them. Paul will later say, "I became weak to the weak, that I might win the weak" (1 Cor. 9:22). This saying has special relevance for his ministry to the Corinthians. Paul's identification with the cross led him to participate in their low estate. Paul was with them in weakness (2:3). He was in this way similar to most of the Corinthians. This served to unite him with them and also to illustrate just how deeply suitable the gospel is to them. The apostle's personal example validates the church's members, given their background, as the sort of people who are - like him - marked for God's involvement. "For look at (the situation of) your calling, brothers: Not many wise according to the flesh, not many powerful, not many well-born" $(1: 26)$.

Paul aims to win the Corinthians to the idea that his weak demeanour serves as a paradigm for believers who desire God's power in their midst. Betz (1967:159) rightly affirms that the Corinthian church is led into the power of the cross of Christ through mimesis of Paul. As in the apostle's own life, God's power will be apparent in a congregation that owns up to its weakness. Paul attempts to teach this pattern to the Corinthians. Power-in-weakness is not only true for the gospel of Christ crucified and for Paul as an apostle. The pattern applies to the Corinthian congregation as well, and as it changes the congregation's convictions about where true power and status lie, it can uproot the foundations of Corinthian boasting and disunity.

In 1 Cor. 4:9-13, Paul's identification with the cross enables him to meet (and go beyond) most of the Corinthians and their lower rungs on the social ladder, even as he also steers them toward a way of life that reflects the cross. ${ }^{13}$ His self-description reminds us of his earlier words about the wisdom of the cross (1:25-31). Although Paul does not say 'cross' or 'crucified' in 4:9-13, the contours of "the message of the cross" (1:18) shape his description of the apostles (Schrage 1991:330; Hays 1999:72; Nguyen 2008:44). Paul characterises their way of life: "I think God has exhibited us apostles last, as sentenced to die" (4:9). "We are fools because of Christ" (4:10). These statements reflect the shame and foolishness of the cross (cf. 1:20-27). Paul is sarcastic as he calls the Corinthians rich, wise, and royal $(4: 8,4: 10)$, but he is dead serious about the apostles. The cross is not the only foolish, weak, and despised spectacle. The apostles are, too. They are dishonoured. They hunger and thirst, go without proper clothing, and are ill-treated. They lack shelter and labour with their own hands. The event of Christ crucified has become the story of their lives. "Paul offers a catalogue of hardships demonstrating that he embodies all that is held in disrepute according to cultural standards and expectations" (Longenecker 2010:254; see also Shi 2008:226-228). This is not the life esteemed by status-conscious Corinth.

Paul's description of the apostolic life takes a curious twist in 1 Cor. 4:12-13. His manner, as shaped by the cross, does not only mean that he places himself with the lowly. It also means, "When reviled, we bless; when persecuted, we endure; when defamed, we encourage" (12b-13a). ${ }^{14}$ The apostles demonstrate powerful capacities in the midst of these

13 This observation with regard to 1 Corinthians 4 grants corroborative evidence for Eastman's approach (2010) with respect to the example of Christ and Paul in Philippians.

14 AT Hanson observes the similarity between 4:12b-13a and Rom 12:14 and reasons that Paul's use of the material from 1 Cor. $4: 12 \mathrm{~b}-13 \mathrm{a}$ in the paraenesis of Romans reflects the reality that "Paul does not mean this sort of life to be restricted to the apostles" (1987:27). 
experiences of weakness. Paul accents not only the weak side but also the powerful side of the apostolic life, as he portrays the cross itself in 1 Corinthians 1-2. The apostles certainly fail to meet some Corinthian standards of power and status, but they exhibit a powerful ability to bless, endure, and encourage. The apostles prove strong in the attributes needed for restoring unity in a congregation.

Paul's personal example in 1 Corinthians 1-4 fills out what he means by the command which concludes this large section of the letter: "Be imitators of me" (4:16). It is much more than a call to relatively high-status church members to identify with the disadvantaged. Paul's words exhort the entire community, including the many believers at the bottom of the social ladder. Even they can lay hold of God's power to bless, endure, and encourage. Just as Paul follows the pattern of Christ crucified, the whole congregation must exercise power in weakness. The believers' vocation reflects both the weakness and the power of the cross. Although Martin (1995:103) claims that Paul aims his call to imitation only at the high-status members of the community, Paul's choice to execute his ministry from a situation of low social status suggests that he has the whole congregation in mind as he encourages them to participate in God's power to bless. ${ }^{15}$

Paul simultaneously identifies with the cross and with the disadvantaged in order to call the Corinthian community to participate in the power of God - not by denying weakness and boasting in human strength, but by owning their weakness and boasting in the Lord. Paul's identification with the cross enables him to identify with the Corinthians. Then when Paul invites the Corinthians to take the path of power-in-weakness which he has taken, he imparts to this congregation of mainly disadvantaged people an identity as a people of power. This strength comes not on account of their association with what their society calls status and power, but on account of their participation in Jesus Christ and the cross. Paul imparts a vocation to walk in the way of the cross and the apostles, to become a people empowered to bless, encourage, and serve. All the members can stand tall and walk in confidence - in the Lord alone. Therefore the congregation need not grasp for sources of pride. Because they need not compete for sources of status and power, their relations with one another can be re-aligned; they can walk in unity.

\section{Renouncing Privileges to Give Preference to the 'Weak': 1 Corinthians 8:1-11:1}

In 1 Cor. 8:1-11:1 Paul deals with an issue which readers today may find obscure at first: Should believers eat meat that has previously been offered up to idols? ${ }^{16}$ Division seems to have erupted between the more sophisticated members who recognise that an idol is really nothing, and the bulk of the members who are less knowledgeable or less accustomed to high-level reasoning (8:7). ${ }^{17}$ Brookins observes that scholars tend to agree that "the 'wise' Corinthians are also the wealthier Corinthians" (2011:55). G Theissen (1982:128ff.) clarifies that the economic status of those whom Paul calls 'weak' would not have allowed them to eat meat on any occasion other than when it had been sacrificed to an idol, so they

\footnotetext{
15 We can also note that, to Paul, all the Corinthians are his children (4:15), so he commands them all. The 'some' ( $\tau$ ives) of 4:18 does not suffice to lead us to read Paul's example as intended only for the elite of the community.

16 This issue was neither small nor isolated, and it forced new believers to ask difficult questions about how they related to their pagan background (cf. Rev. 2:20).

17 Paul himself does not say it is the bulk of the members. Here he is polite, but other indications in the letter suggest that most of them would be in this category (cf. 1:26; 9:22).
} 
associated eating meat with returning to pagan worship. The apostle theoretically agrees with the higher-status members' position, yet he counsels the congregation: "Knowledge puffs up, but love builds up" (8:1b). Paul also warns lest their freedom become a stumbling block or hindrance for those in their congregation who are weak - those with less knowledge and a tender conscience based on limited knowledge (8:9-10). Paul expresses the gravity of destroying the brother who is weak; he is one "for whom Christ died" (8:11). Thus Paul again turns the Corinthians to the central event of the gospel, Christ's death for others, to guide them in their treatment of those who are somehow disadvantaged.

When interpreting Paul's call to the Corinthians in 1 Cor. 11:1 to "Imitate me, as I imitate Christ", we must remember Christ as the one who died for the weak brother (8:11). Scholars tend to miss this one reference to an action of Christ in 1 Cor. 8:1-11:1. ${ }^{18}$ It is the type of deed done by Christ that both Paul and the Corinthians should imitate. Paul reasons that if Christ sacrificed himself by dying for the weak, then those who are strong in knowledge can at least adjust their eating habits. The example of Christ crucified directs the church to give priority to the underprivileged.

In 1 Corinthians 9, Paul describes his own privileges which he gave up for the sake of the weak and for the progress of the gospel. Paul refers to himself more in 1 Corinthians 9 than any other section of the letter, but we also find forms of the stem $\varepsilon \dot{u} \alpha \gamma \gamma \varepsilon \lambda$-('gospel') as frequently in this chapter as anywhere else in the Pauline corpus. ${ }^{19}$ This is no accident. Paul binds his personal example to the message of the gospel, which in 1 Corinthians is, in essence, Christ crucified. ${ }^{20}$ Throughout chapter 9 we see the pattern of Christ's death for others reflected in Paul's renunciation of his apostolic privileges. ${ }^{21}$ As Paul substantiates his privileges $(9: 1,4,5,12)$, this serves his larger goal of instructing the Corinthians in surrendering liberties for the sake of the weak in their midst, and for the advance of the gospel. The gospel does not merely shape Paul's words; it moulds his way of life and the example he sets, even as he pursues the gospel's advance. ${ }^{22}$ Thus Paul cannot explain his manner of life apart from the gospel. We must bear this in mind when Paul concludes this large section of 1 Corinthians by calling on the congregation to imitate him.

In 1 Cor. 9:19-23, Paul speaks of his actions alongside preaching the gospel and of the purpose behind these actions. In 9:19, he affirms that although he is free to exercise his rights as an apostle, he has instead made himself a slave ( $\dot{\delta} \delta$ où $\omega \sigma \alpha)$ for all people, in order

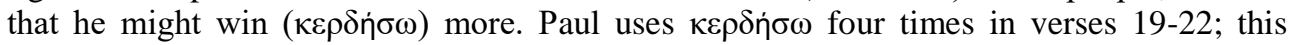
would likely bring to the Corinthians' minds the pursuit of financial profit, since the term is often used in the realm of business (Matt 16:26; 25:16-22; James 4:13; but cf. Matt 18:15; Phil 3:8). However, Paul utilises the word in an unexpected way. With each use of

18 Castelli (1991), Fee (1987), Thiselton (2000), and Fitzmyer (2007) fail to mention 8:11 when interpreting 11:1; referring to 8:11 would have strengthened the case of Fee and Thiselton that Paul thinks of Christ's death as a model when he calls the believers to imitate him in 11:1.

19 The stem appears seven times in 9:12-18, plus once more in 9:23. Galatians 1-2 is the other passage with the highest concentration.

20 On account of Paul's repeated emphasis on Christ's resurrection in 1 Corinthians15:1-4 ff., the resurrection is also implicit in the message of Christ's death within the letter's preceding chapters.

21 See Boff, who summarises his discussion of Paul's theology of the cross in 1 Corinthians as "Not Freedom from Others, but Freedom for Others" (1987:80-81).

22 For the unity of Paul's way of life with his gospel, see Schutz (2007:203 ff., and 190), who demonstrates that Paul's apostolic manner is "an embodiment of the gospel ('the word of the cross')" (2007:203). See also Shi (2008:1), who states: "The message of the cross refers not only to the content of Paul's gospel, but also to the manner of his proclamation and delivery as well as his apostolic life." See also Ellington (2011:308) and Hurtado (2004). 
$\kappa \varepsilon \rho \delta \eta ் \omega$, Paul maintains that the gospel of Christ crucified redefines what Christians attempt to gain: other people. Paul claims that he aims to win as many as he can and therefore makes himself a slave to all.

Paul's mention of self-enslavement ( $\dot{\varepsilon} \delta$ oú $\lambda \omega \sigma \alpha)$ might have surprised the Corinthians. This was perhaps not easy on the ears of the relatively high-status members of the Corinthian church. For the congregation's disadvantaged members, however, the apostle's reference to himself as a slave may have been validating. Certainly the term would have been understandable to all: To be a slave is to live for another's benefit or profit (Martin 1990:51). Paul means that he relinquishes his freedom to live as he pleases in order to do, and become, what is best for the gospel's progress among the people he seeks to win.

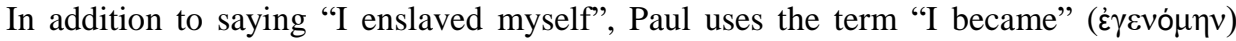
four times, and implies it two more times, in 9:20-23. By emphasising what he becomes, Paul models personal adjustments for the sake of his purpose. Paul mentions that he has become various things for the sake of the gospel, but what he names just before saying he has become all things to all people is particularly essential for the Corinthians: "I became weak to the weak, that I might win the weak." This is highly significant for how those in Corinth who are strong in knowledge, and also stronger in their economic status (Brookins 2011:55), must interpret the call to imitate the apostle. Paul calls the more elite members to adapt their way of relating to fit the rest of the congregation. ${ }^{23}$ Paul models behaviour so that the believers learn to act in a way that serves the salvation and wellbeing of the disadvantaged members. Paul prioritises what is best for the weak.

The climax of 1 Corinthians 9 is verse 23, where Paul says he does all things for the

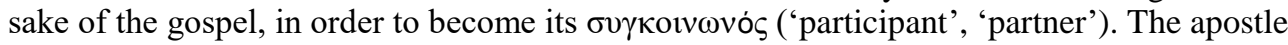
uses this term to indicate that he shares and participates in the gospel's pattern and powerof Christ's death for others. ${ }^{24}$ Paul also means that he aims to work together with the gospel

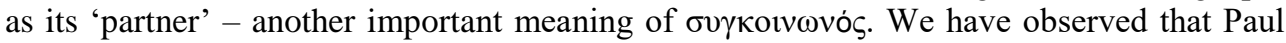
makes himself a slave; that is, he lets go of his prerogatives and renounces his rights for the sake of others. This is Paul's way of imitating the pattern of Christ's death for others.

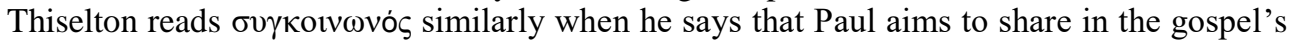
nature, "to instantiate what the gospel is and how it operates" (2000:707). When Paul calls the congregants to imitate him as he imitates Christ in 11:1, he means that the Corinthians

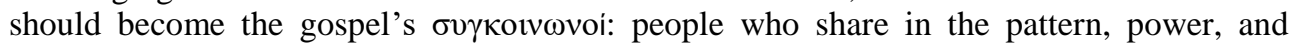
progress of the gospel.

In addition to offering himself as a positive example in 1 Corinthians 9, Paul submits the 'fathers' in 10:1-13 as a negative example of those who stumble and fall. The apostle tells the congregation that it was not enough that the ancestors in the faith were baptised into Moses and drank from the rock that was Christ. Despite their preliminary form of participation in Christ, their bodies lay strewn across the wilderness. As "types for us" (10:6; cf. 10:11), the incidents prefigure the life of the church (Hays 1997:162), and Paul tells the community (in particular, the strong) to take heed lest they fall (10:12). Even as the community is one because of their common participation in Christ (10:17), this union with Christ must also lead to embodied expression. ${ }^{25}$ For Paul, true participation in Christ carries

\footnotetext{
23 K Ehrensberger (2003:256) elucidates Paul's actions in 9:19-22: “To accommodate to him/her in his/her difference as Paul does (9:19ff.) is proper imitation of Christ... Accommodation serves the purpose of supporting the other on his way to salvation."

24 Ellington 2011:309-312. Some of the present article's exegetical points from 1 Cor. 8:1-11:1 appear there, despite that article's different argument and focus.

25 Although outside the scope of this essay, the relationship between Paul's concern for the disadvantaged and his Christology, and specifically his understanding of believers' union with Christ, deserves attention. The
} 
within it an impulse to be like the one who died for others, and thus to act and live for the advantage of others. The apostle summarises: "Let no one seek his own good but that of the other" (10:24). To be true to Christ and the gospel, the church must love and build up the weaker members.

When Paul concludes this section of 1 Corinthians by saying, "Be imitators of me, as I (am an imitator) of Christ," he calls the Corinthians to be sharers in the gospel's pattern, power, and progress, even as he himself is. Like Paul, the members of the Corinthian church must work with, not against, the impulse of the gospel. The gospel itself directs the Christian life. ${ }^{26}$ As Paul calls his audience to participate in the gospel's pattern and power, the gospel's goal becomes their aim: the salvation of others, of whom most are the weak. ${ }^{27}$ In the Corinthian context, this means learning to be a church that carries out its life in a way that is sensitive and preferential toward the disadvantaged. Paul asks the Corinthians to adjust their eating habits and thus make sacrifices in the quality of their lives. By renouncing such prerogatives for the sake of the economically and socially vulnerable, believers join Paul in working with, and being propelled by, the impulse of the gospel.

\section{Conclusion}

This article has examined two major sections of 1 Corinthians, 1:10-4:21 and 8:1-11:1, in which we recognise an impulse toward the disadvantaged within the gospel as preached by Paul. The apostle affirms, and in no way denies, that the gospel of Christ crucified is the power of God for salvation to those who believe (1 Cor. 1:17-18, 21; 15:1-4). However, as important as Christ and his death are for the message Paul proclaims, in 1 Corinthians the apostle focuses on the cross in order to establish just and unified relationships among believers, especially to benefit the disadvantaged. This study, though not exhaustive, ${ }^{28}$ has demonstrated how the apostle perceives the gospel of Christ's death for others as a driving power and motivating model that moves the church toward care for the vulnerable. The investigation of 1 Cor. 1:10-4:21 and 8:1-11:1 stands as a witness to the holistic nature of Paul's good news.

In 1 Corinthians, Paul aims to draw discordant groups together as a distinct Christian community and culture, complete with new conventions for approaching status and power in the light of the cross. By identifying the power of God in the cross, Paul argues that Christ's death turns upside down the Corinthians' prior assumptions. As Paul forms the

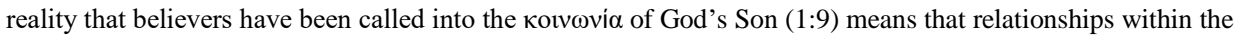

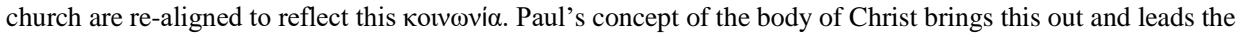
apostle to the corollary that no member is unimportant. Those in the church whom we are tempted to overlook as weak and less honourable, Paul labels 'indispensable' (12:22). God has chosen greater honour for those we tend to treat as less respectable (12:24). The suffering of one is the suffering of all (12:26). Corinth was marked by social competition, yet Paul's letter came to the Christians in this city in order, at least partly, to persuade them that care and honour are available for all; union with Christ was a key basis for this argument. See the fuller discussion in Gorman (2010:36-37).

26 Boff, with 1 Corinthians in mind, affirms that "the cross of Christ has become the criterion of Christian wisdom"; the cross "is also the measure of the Christian's concrete behaviour" (1987:81).

27 J Barclay observes that it is highly difficult to reconstruct exactly the economic makeup of the Pauline churches, but that "most of Paul's converts ... lived at or near subsistence level" (2004:365). See also SJ Friesen (2004:348).

28 More could be explored regarding the precise relationship between 'weakness' and 'power' in Paul's terminology. Moreover, the link between Paul's concern for the disadvantaged and his Christology in 1 Corinthians - specifically his understanding of believers' union with Christ - deserves attention (see footnote 25). 
community through reflection on Christ's death, he inculcates new concepts of power and status that can replace the Corinthians' former standards.

Paul's own example embodies the new way of operating in the manner of the cross. $\mathrm{He}$ calls the Corinthians to imitate him, and thereby to embody the gospel themselves. Whereas weakness was previously shameful, in the cross God validated human weakness as the chosen arena for expressing divine power. In the cross we also see Jesus' example of sacrificing himself for the weak. Paul takes up Christ's example by renouncing privileges for the sake of the socio-economically vulnerable. Paul teaches the Corinthians to imitate him by limiting their privileges for the sake of the 'weak' in their midst, such as by eating in ways that do not become a stumbling block for them (1 Cor. 8:1-11:1).

Paul also imparts to the Corinthians a deep identification with Jesus Christ and the gospel. Through the gospel of Christ crucified, this congregation of mainly disadvantaged people receive the presence and power of God. The whole congregation, the weak included, thereby receives an identity as a people of power - able to bless and encourage others, and to endure hardship (4:12-13). They also receive the dignity of partnership with the gospel, as they reproduce its pattern, move with its power, and live for its progress (9:19-23). At the same time, Paul's redefinition of status eliminates boasting in human strength, success, or recognition. Paul teaches the believers to take pride in and identify themselves with Jesus Christ and the gospel (1 Cor. 1:31; 3:21, 23; 9:23; 11:1). With new sources of strength and pride which eliminate the need to compete in their relationships, they operate differently with one another, as a unified congregation.

Now that we have observed the impulse toward the vulnerable within Paul's gospel, some may naturally ask: why do the apostle's words not pursue an agenda of social justice even further? For instance, why did Paul not allow the impulse to take him further in regard to slavery, or the role of women? These are questions that deserve more attention than this conclusion allows, but it is essential to keep three matters in mind. First, Paul is writing an occasional letter, responding to situations and questions as he writes to the Corinthians (1 Cor. $1: 11 ; 5: 1 ; 7: 1$ ), not giving the last word on topics such as slavery and the role of women. Second, Paul answers questions and counsels believers based on his eschatological understanding that "the time is short" (7:29); he teaches the Corinthians in the light of what he believes will be Christ's impending return (1:7-8). ${ }^{29}$ Third, it is highly possible that the impulse of Paul's gospel to elevate the disadvantaged, even though it acts as a driving force in 1 Corinthians, is something that still remains embryonic in Paul's thought. As Boff (1987:78) observes, meanings and implications of Christ's death came gradually, not all at once, to earliest Christianity.

Finally, what does the drive to elevate the disadvantaged, which we find in Paul's gospel, mean for Christians in Africa today? For those of us who claim Paul's understanding of the gospel as our own, we must recognise that, since the impulse toward the disadvantaged comes from the gospel itself, socioeconomic issues cannot be left at the periphery of how believers live and reflect on the Christian faith. Although justice for the weak is not the gospel itself, it is integral to the gospel (see also Longenecker 2010:316).

In light of this study's observations about the gospel's impulse toward the disadvantaged, we must reflect on the question: Who should the church honour with status and privilege? The African church needs to wrestle with its proclivity to give the greatest

29 Longenecker (2010:138), however, deftly explores how the reality of Christ's imminent return means that Paul goes about forming congregations that are as much as possible like the new age which is dawning. Longenecker takes Paul's work at unifying Jew and Gentile as evidence. 
esteem to believers who are successful, wealthy, and powerful by standards which are not derived from Christian teaching. As one who trains pastors in Zambia, I frequently hear of social shame that accompanies Christians who lack financial means. For instance, if a minister goes about on foot or by bicycle instead of by car or motorcycle, fellow believers tend to sneer, saying the God he/she preaches must be small. This attitude suggests a deep misunderstanding of the Christian God and the Christian gospel. ${ }^{30}$ Rooted in the incarnation and crucifixion, the concept of power-in-weakness arises from the foundation of the Christian faith. Barton rightly affirms that "in its literary deposit and common life, early Christianity represents a re-narration of what really counts and how to attain it" (2009:56). The church needs to allow Scripture and the gospel to do the same today. What we proclaim and do as Christians must reflect and continue this re-narration in our own contexts.

Instead of buying into modes of thought about status that have little relation to Christian faith, we must opt for Paul's approach in 1 Corinthians, where he keeps addressing the problem that believers place their confidence in the wrong places, namely in various forms of human strength. Paul's convictions about Jesus' death on the cross, and power in weakness, led him to practice and teach a spirituality that privileged the disadvantaged and gave status to them. Africa's Christians unabashedly believe the gospel of Christ crucified for human sin. Since this is so, the church also needs to recognise the impulse toward the disadvantaged, which comes from the same gospel of Christ crucified, in order to fulfil the calling of God's people to social relationships marked by justice. To be faithful to the gospel, believers must never despise or shame a fellow believer who is poor. We who are Christians belong to a community that preaches the gospel and exemplifies a life shaped by the gospel - often in ways quite reversed from outside definitions of status and power.

\section{BIBLIOGRAPHY}

Barclay, J 2004. "Poverty in Pauline Studies: A Response to Steven Friesen.” Journal for the Study of the New Testament 26.3:363-366.

Barrett, CK 1968. First Epistle to the Corinthians. New York: Harper \& Row.

Barton, S 2009. "Money Matters: Economic Relations and the Transformation of Value in Early Christianity." Pages 37-59 in Engaging Economics: New Testament Scenarios and Early Christian Reception. Edited by B Longenecker and K Liebengood. Grand Rapids: Eerdmans.

Betz, HD 1967. Nachfolge und Nachahmung Jesu Christi im Neuen Testament. Tübingen: JCB Mohr.

Boff, L 1987. Passion of Christ, Passion of the World: The Facts, their Interpretation, and their Meaning Yesterday and Today. Maryknoll, NY: Orbis.

Brookins, T 2011. "The Wise Corinthians: Their Stoic Education and Outlook.” Journal of Theological Studies 62.1:51-76.

Castelli, E 1991. Imitating Paul: A Discourse of Power. Louisville: Westminster John Knox.

30 Boff (1987:81) states: "Those who ... sneer at the weak ... may as well sneer at the crucified Jesus himself, as well, and curse him. And indeed they do. But they forget that it was in weakness that God has revealed power and salvation." 
Ciampa, R and B Rosner 2010. The First Letter to the Corinthians. Grand Rapids: Eerdmans.

Downs, D 2009. "Was God Paul's Patron? The Economy of Patronage in Pauline Theology." Pages 129-156 in Engaging Economics: New Testament Scenarios and Early Christian Reception. Edited by B Longenecker and K Liebengood. Grand Rapids: Eerdmans.

Eastman, S 2010. "Philippians 2:6-11: Incarnation as Mimetic Participation." Journal for the Study of Paul and his Letters 1.1:1-22.

Ehrensberger, K 2003. “'Be Imitators of Me as I am of Christ': A Hidden Discourse of Power and Domination in Paul?" Lexington Theological Quarterly 38:241-61.

Ellington, DW 2011. "Imitating Paul's Relationship to the Gospel: 1 Corinthians 8.1-11.1." Journal for the Study of the New Testament 33.3:303-315.

Fee, G 1987. The First Epistle to the Corinthians. New International Commentary on the New Testament. Grand Rapids: Eerdmans.

Fitzmyer, J 2007. First Corinthians. Anchor Yale Vol. 32. New Haven: Yale University Press.

Friesen, SJ 2004. "Poverty in Pauline Studies: Beyond the New Consensus." Journal for the Study of the New Testament 26.3:323-361.

Friesen, SJ, DN Schowalter, JC Walters, (eds.) 2010. Corinth in Context: Comparative Studies on Religion and Society. Supplements to Novum Testamentum 134. Leiden: Brill.

Gorman, MJ 2001. Cruciformity: Paul's Narrative Spirituality of the Cross. Grand Rapids: Eerdmans.

Gorman, MJ 2010. "Justification and Justice in Paul, with Special Reference to the Corinthians." Journal for the Study of Paul and His Letters 1.1:23-40.

Hanson, AT 1987. The Paradox of the Cross in the Thought of St Paul. Sheffield, England: Sheffield Academic Press.

Hansen, B 2010. 'All of You Are One': The Social Vision of Gal. 3.28, 1 Cor. 12.13, and Col 3.11. London: T\&T Clark.

Hays, RB 1997. First Corinthians. Louisville: John Knox Press.

Hurtado, L 2004. “Jesus' Death as Paradigmatic in the New Testament." Scottish Journal of Theology 57.4:413-33.

Longenecker, B 2010. Remember the Poor: Paul, Poverty, and the Greco-Roman World. Grand Rapids: Eerdmans.

Malcolm, MR 2013. Paul and the Rhetoric of Reversal in 1 Corinthians: The Impact of Paul's Gospel on His Macro-Rhetoric. SNTSMS 155. Cambridge: Cambridge University Press.

Martin, D 1990. Slavery as Salvation: The Metaphor of Slavery in Pauline Christianity. New Haven: Yale University Press.

Martin, D 1995. The Corinthian Body. New Haven: Yale University Press.

Meggitt, J 1997. "Laughing and Dreaming at the Foot of the Cross: Context and Reception of a Religious Symbol.” Pages 63-70 in Modern Spiritualities: An Inquiry (ed.)

Laurence Brown et al. Oxford: Prometheus Books.

Millis, BW 2010. "The Social and Ethnic Origins of the Colonists in Early Roman Corinth." Pages 13-36 in Corinth in Context: Comparative studies on religion and society. Edited by SJ Friesen, DN Schowalter, JC Walters. Supplements to Novum 
Testamentum, 134. Leiden: Brill.

Nguyen, VHT 2008. “God's Execution of His Condemned Apostles: Paul's Imagery of the Roman Arena in 1 Cor.4, 9." Zeitschrift für die neutestamentliche Wissenschaft 99:33-48.

Pickett, R 1997. The Cross in Corinth: The Social Significance of the Death of Jesus. JSNTS 143. Sheffield: Sheffield Academic Press.

Schowalter, DN and SJ Friesen, (eds.) 2005. Urban Religion in Roman Corinth: Interdisciplinary Approaches. Cambridge: Harvard University Press.

Schrage, W 1991. Der Erste Brief an die Korinther, I. Düsseldorf: Benziger Verlag. Schutz, JH 2007 [1975]. Paul and the Anatomy of Apostolic Authority. Louisville: Westminster John Knox.

Shi, W 2008. Paul's Message of the Cross as Body Language. WUNT 2, 254.Tübingen: Mohr Siebeck.

Stafford, T (ed.). 2016. God's Justice: The Holy Bible. Colorado Springs: Biblica.

Theissen, G 1982. The Social Setting of Pauline Christianity. Philadelphia: Fortress Press. Thiselton, AC 2000. The First Epistle to the Corinthians. Grand Rapids, Michigan: Eerdmans.

Thiselton, AC 2006. "The Significance of Recent Research on 1 Corinthians for Hermeneutical Appropriation of this Epistle Today." Neotestamentica 40.2:320-352. 